\title{
Time-series cross-sectional environmental performance and disclosure relationship: specific evidence from a less-developed country
}

\author{
Aminu Hassan*, Reza Kouhy \\ Division of Accounting, Finance \& Economics, Dundee Business School, Abertay University, Dundee \\ *Corresponding author E-mail: a.hassan@abertay.ac.uk
}

\begin{abstract}
This paper relies on 'vulnerability and exploitability' framework to submit new insights into legitimacy theory and voluntary disclosure theory using specific empirical evidence from the Nigerian oil and gas industry. The study connects the voluntary and legitimizing disclosure behaviors, regarding carbon emission due to gas flaring, of dominant companies in the Nigerian upstream petroleum sector to the vulnerability and exploitability of Nigeria as a less developed country. The hypothesized relations between gas flaring-related environmental performance and two forms of its disclosure (volume and substance) are estimated and tested using Prais-Winsten regression with Panel Corrected Standard Errors (PCSE). While the paper uses Data Envelopment Analysis (DEA) to measure gas flaring-related carbon performance, the two forms of gas flaring-related disclosures are measured using content analysis. We document significant positive and negative association between gas flaring-related carbon emission performance, on one hand, and the volumetric disclosure and disclosure substance on the other hand. These results imply that while the positive relation confirms the vulnerable nature of Nigeria as a less developed country, the negative relation is linked to the country's exploitability. It is also empirically established that environmental performance is one of the key factors responsible for the undulating trend in the volume of environmental disclosures by large corporations operating in less-developed countries
\end{abstract}

Keywords: Carbon Emission, Environmental Performance, Environmental Disclosure, Exploitability, Gas Flaring, Vulnerability.

\section{Introduction}

Emission of carbon dioxide, argued as being responsible for adverse global climate change, is receiving increasing attention in a number of disciplines including accounting. Accounting researchers' concern for carbon emission is traceable to the discipline's longstanding interest in environmental reporting (Stechemesser \& Guenther 2012). In this context, Stechemesser and Guenther (2012) describe carbon accounting as a specific incorporation of climatechange issues into accounting and reporting. Carbon accounting is, therefore, an aspect of the mainstream Social and Environmental Accounting (SEA) concerned with specific environmental accountability relating to greenhouse-gas emission. Although, carbon accounting is without a doubt a nascent area of accounting research, it has amazingly recorded numerous research publications over the last few years. Thus, Stechemesser \& Guenther (2012) compile and review 129 publications on carbon accounting in their quest to derive a coherent definition of the concept from the relevant literature. Inference from the relevant literature unveils that the main concern of both research and practice of carbon accounting involves measurement of carbon performance and carbon emission indexes, greenhouse-gas emissions reporting (Ascui \& Lovell 2011, 2012, Freedman \& Jaggi 2005, Sulliva \& Gouldson 2012) and provision of information that supports managerial decisions with sustainability implications (Stechemesser \& Guenther 2012, Ascui \& Lovell 2012, Scipioni et al. 2012, Tsai et al. 2012).

This current paper, which is ultimately concerned with measurement and examination of the relation between gas flaring-related
(GFR) carbon emission performance and disclosure, belongs to carbon accounting. The paper is specifically situated within the environmental performance and disclosure relationship research niche. A specific source of carbon emission arising from the production of hydrocarbons is burning of associated natural gas. Oilproducing countries at the forefront regarding flaring of associated natural gas include, stated in descending order, Russia, Nigeria and Iran (see, Hassan \& Kouhy 2013). Nigerian natural gas is scientifically classified as sweet, implying that it has very high methane content, and when methane (CH4) is burnt, it converts to carbon dioxide $\left(\mathrm{CO}_{2}\right)$. Consequently, flaring of ANG in the upstream sector of the Nigerian oil and gas industry represents releases of $\mathrm{CO}_{2}$, and this contributes significantly to climate change. The paper aims to estimate and analyze the relation between carbon emission performances (CEP), due to gas flaring, and GFR disclosures with a view to examining the level of commitment with which dominant companies operating in the Nigerian upstream sector are making efforts to minimize wasteful flaring of this energy resource and its associated adverse environmental impacts.

In a recent paper on social and environmental accountability in emerging and less-developed countries, Belal, et al. (2013) have provided an interesting link between "vulnerability and exploitability" and poor discharge of social and environmental accountability by Multinational Corporations (MNCs). Thus, the authors contend that the evident vulnerable and exploitable nature of, especially less-developed countries, has left them open to being taken advantage of by MNCs. Vulnerability in relation to less-developed countries has been linked to their exposure to inherent poverty and risks (Blaikie et al. 1994, Montalbano 2011). The relation between 
vulnerability and poverty could be explained in terms of weaknesses in governments, pressure groups and individual members of the society to respond with firmness and resilience to negative impacts. These negative impacts may be inflicted by either corporate entities or an advanced country, and they may take the form of exorbitant prices, resource exploitation at very little or no cost and adverse environmental impacts. Thus, governments and individual members of less-developed countries do sacrifice the discharge of environmental accountability expected from MNCs in favor of income generation, employment provision and provision of goods/services by these companies. As such, these countries are open to many risks due to their vulnerable relationship with large MNCs. Consequently, they run the risk of sustaining adverse environmental impacts devoid of any accountability by the parties responsible for the impacts. Consistent with Belal et al. (2013) we argue that the vulnerable nature of less-developed countries and the abundance of both human and natural resources make them easily exploitable. Exploitability is made possible by depraved a government, weak regulations, large poverty-stricken population and abundance of valuable resources. In this context, we submit empirical evidence from the Nigerian oil and gas industry regarding the nature of the relation between GFR carbon emission performance and disclosures to provide further explanation on the vulnerable and exploitable nature of less-developed countries.

Dearth of research regarding SEA accountability in less-developed countries has been variously noted (Belal et al. 2013). Nonetheless, it is evident that related research on this subject in developing countries is steadily growing (Elijido-Ten 2011). This paper seeks to contribute to this underdeveloped area of research. Some previous studies on environmental reporting in less-developed countries have documented undulating trend in the volume of what is being disclosed by corporations over time (see, for example, Tsang 1998, Jamil et al. 2002, de Villiers \& van Staden 2006). The question as to why the rise and fall over time, as against a continuous increase in the case of results documented by studies in developed countries (see, for example, Guthrie \& Parker 1990, Gray et al. 1995, Campbell 2004, KPMG 2008), is still unresolved. Although, de Villiers and van Staden (2006) have attributed the undulating trend in the volume of environmental disclosure in the context of South Africa to legitimizing efforts, they have failed to empirically identify any specific variable or variables responsible for the scenario. We suspect that this undulating trend may be specifically due to the influence of environmental performance on environmental disclosure across companies and over time. We underpin this relation with legitimacy and voluntary disclosure theories and attempt to explain the environmental reporting behavior of large corporation operating in less developed country using the framework of "vulnerability and exploitability". Our study focuses on a pacific environmental performance and disclosure relationship relating to carbon emission due to gas flaring. Consequently, the paper seeks to address two objectives. Firstly, we examine the relationship between GFR environmental performance and its volumetric disclosure with a view to providing empirical evidence about vulnerability. Secondly, we evaluate the relation between GFR environmental performance and its disclosure substance to provide empirical support for exploitability.

The paper is organized as follows. The next section is devoted to review of relevant literature, revisiting theoretical underpinnings and development of the research hypotheses. Such methods as DEA, Praise-Wisnten regression with panel corrected standard errors and empirical results are discussed next. Results presented in the preceding section are discussed in the penultimate section in the light of legitimacy theory, voluntary disclosure theory and the concepts of 'vulnerability and exploitability'. In the final section, we conclude our study and discuss some limitations.

\section{Revisiting related literature and theories}

Empirical investigation conducted to explore insights into firms' environmental responsibility behaviors, and the reporting practices of such behaviors has indeed attracted attention in SEA research. An important aspect of this research investigates whether firms' environmental performance reported represents their actual performance. This involves an attempt to answer the question: how environmentally accountable are firms? Studies involved in this kind of investigation are concerned with the relationship between firms' environmental performance and disclosures. This current study belongs to this group.

\subsection{Measurement of environmental performance}

It is a general consensus that measurement of the construct, environmental responsibility, is complex (Ingram \& Frazier 1980, Freedman \& Wasley 1990, Waddock \& Graves 1997, Patten 2002, Orlitzky et al. 2003, Nawrocka \& Parker 2009). It is, therefore, usual to operationalize this construct through the measurement of the efforts firms have made to ameliorate their negative environmental impacts (Wood 1991, Ilinitch et al. 1998, Tyteca 1996, Waddock \& Graves 1997). Measurement of environmental performance is a common area of interest in accounting, management and economics. Measurement of this variable as an area of intersection between the three disciplines is linked to the multidisciplinary nature of corporate environmentalism (see, Desjardins 2001). While accounting and management are mainly concerned with measurement of environmental performance at firm level, researchers in environmental economics are concerned with measurement of the variable at plant level, firm level, industrial level and country level (Tyteca 1996).

\subsubsection{Measurement of environmental performance in account- ing and management}

It is argued that researchers in the field of social and environmental accounting should participate in the measurement and evaluation of firms' environmental performance (see, Abbott \& Monsen 1979, Mathews 1993, Ilinitch et al. 1998). Specifically, Mathews (1993, p. 6) implies this argument in the following excerpt.

"The position argued is that a more socially responsible accounting may be justified and should be implemented, not to radically change society but to modify and improve our present system, by including measurement and reporting relationships, which are currently excluded".

In a similar vein, Ilinitch et al. (1998) observe that although, there has been a growing attention on the environmental activities of companies by different stakeholders, the accounting profession is lagging behind in assuming, in earnest, the role of defining, measuring and controlling environmental performance. They further argue that the accounting profession is one of the disciplines that ought to involve in environmental performance measurement, since among the subject matters of the field are measurement, communication and regulation of information regarding the performance of business firms. Measurement of environmental performance is prevalent in the area of SEA, particularly among researchers interested in the relation between environmental performance and disclosure, or the association between environmental performance and economic performance. Most researchers in these two sub-areas of environmental accountability mainly rely on environmental performance indexes developed by various rating agencies for the purpose of their studies. There are many different kinds of indexes developed by such various rating agencies as Council on Economic Priority, Truecost, KLD, and Coalition for Environmentally Responsible Economies (CERES), Business and Society Review (BSR), Industry Rates Itself, Investor Responsibility Research Center (IRRC) and Franklin Research Development Corporation (FRDC). Consequently, diversity of measurement strategies leading to the generation of non-standardized and non-theory-based environmental performance measurements (see, Tyteca 1996, Färe et al. 1996, Tyteca 1997, Orlitzky et al. 2003), has been identified as one of the reasons for the inconclusiveness and mixed findings regarding the nature of the relationship between environmental performance and disclosure (Patten 2002, Clarkson et al. 2011). 
Researchers concerned with the measurement of environmental performance in the management literature are mainly interested in examining the relationship between environmental performance and financial performance (see, Griffin \& Mahon 1997, Cormier \& Magnan 1997, Waddock \& Graves 1997, Konar \& Cohen 2001, Orlitzky et al. 2003, López-Gamero et al. 2009, Horváthová 2010). Others are interested in the relation between environmental performance and environmental management system (for example, Sulaiman \& Ahmad 2002, Gimenez et al. 2003, Berry \& Rondinelli 1998, Ann et al. 2006, Perotto et al. 2008, Nawrocka \& Parker 2009, Johnstone \& Labonne 2009, Iraldo et al. 2009). Measurement strategies employed in these two sub-areas are very similar to those adopted in accounting. For researchers in this field also rely mainly on indexes developed by rating agencies.

\subsubsection{Measurement of environmental performance in econom- ics}

In the literature of environmental economics, there exist two general approaches to the measurement of environmental performance. These are parametric and nonparametric approaches. The parametric approach involves those techniques that require a priory weighting, uniform unit of measurement and other relevant econometric requirements to measure environmental performance (Caves et al. 1982, Pitman 1983, Färe et al. 1993, Färe et al. 2005, Färe et al. 2006, Cuesta et al 2009). Nonparametric approach, on the other hand, involves the use of Data Envelopment Analysis (DEA) based on the mathematical technique of linear programming to develop environmental performance indexes for homogeneous decision making units (DMU) that are using similar multiple inputs to produce multiple desirable and undesirable outputs (Hua \& Bian 2007).

DEA models used for measuring environmental performance are formulated in reference to two alternative improvement technologies in relation to undesirable production outputs, namely strongly disposable technology and weakly disposable technology (Färe et al. 1989, Tyteca 1996, Hua \& Bian, 2007). Under strongly disposable technology, DMUs can discharge pollutants freely without incurring any cost. As such, a production process is said to possess strong disposability property if its resultant undesirable outputs are freely disposable. However, a production process, in relation to bad output, is said to exhibit weakly disposable technology, if the disposal of such bad output cannot be carried out without incurring any form of cost. It is argued that weakly disposable technology is applicable in situations where reduction in bad output results to a decreased production of desirable output as an opportunity cost (Zaim 2004, Hua \& Bian 2007). In DEA formulation, this cost is incorporated as an opportunity cost which takes the form of unwanted decreases in the desirable production output (Zaim 2004). However, when the relation between the pollutant and one or more desirable output is asymmetric the resultant decrease in the desirable output is used as a convenient way of incorporating the weak disposability property in the modeling (Färe et al. 1989). For instance, increases in the volume of associated natural flared lead to a proportional decreases in the volume of associated gas utilized. Although, there were many attempts to account for environmental pollutions in the measurement of firms' productive efficiency (see, Pittman 1983, Färe et al. 1989, Färe et al. 1993), the work of Tyteca (1996) marks the turning point regarding the measurement of 'standardized' and 'pure' environmental performance index. Studies conducted prior to Tyteca $(1996,1997)$ did not make a specific attempt to define and quantify 'pure' environmental performance indexes. They rather emphasized on the general productive efficiency measurements that accounted for environmental impacts. Tyteca (1996), first reviews the literature on prior studies in respect of measurement strategies of environmental performance, concluding that such prior attempts to measure 'pure' environmental performance are disparate, non-standardized and lack general applicability across firms, industries or nations. This is consistent with the view expressed by Ilinitch et al. (1998). Specif- ically, Tyteca (1996, p. 282) states the aim of his study in the following words:

"We look for one (or a few) instrument(s) that would allow us to account for the various possible environmental impacts of industrial activities, and to compare in this respect analogous units in a set, i.e. either plants in a firm or firms in an industry or even industrial sectors in an economy, or to monitor the behavior of any of these units over time".

It can be inferred from this aim that Tyteca (1996) constructs the bedrock on which subsequent works, (for example, Tyteca 1997, Zaim 2004, Zhou et al. 2009) on nonparametric activity analysis methodologies facilitating the development of "pure" environmental performance, were built. The methodology of DEA has evolved so robustly that it even facilitates measurement and evaluation of environmental performance for countries (see, Färe et al. 2004; Zaim, 2004). In addition, it also facilitates panel and time-series analysis of environmental performance via DEA window analysis and Malmquist indexing method respectively.

There are many studies that have relied on the formulation of DEA models for the development of environmental performance indexes (see, for example, Färe et al. 1989; Färe et al. 1996; Tyteca, 1996; Tyteca, 1997; Seiford \& Zhu, 2002; Färe et al. 2004; Zhou et al. 2006; Zhou et al. 2009). However, this study streamlines and focuses particularly on the works of Färe et al. 1989, Tyteca (1996) and Tyteca (1997). Färe et al (1989) adopts Pittman (1983) idea for modeling desirable and undesirable outputs separately. However, their approach differs from that of Pittman (1983) because it involves modification of Farrell (1957) modeling of technical efficiency to measure performance and the specification of Shepherd (1970) directional distance function as its reciprocal (see, Färe et al. 2004). Basically, Färe et al. (1989) use hyperbolic efficiency measures to develop productivity efficiency indexes which account for environmental pollution in the framework of both strongly and weakly disposable technologies. Since, flaring of ANG by companies operating in the Nigerian upstream sector, forces oil and gas companies to incur certain costs (penalty for flaring associated natural gas); it is the assumption of weakly disposable technology that is appropriate in this study. This is basically because the available/accessible data collected for the measurement of gas flaringrelated environmental performance and the asymmetric nature of the relation between ANG utilized and ANG flared deem the combined adoption of the two approaches appropriate. For this reason, Färe et al. (1989) formulation of the case for strongly disposable technology is not reviewed. Consequently, we contend that reviewing other approaches that are not directly relevant to this study is tantamount to unnecessary distraction.

As stated earlier, the first attempt to model pure environmental performance index was made by Tyteca (1996). Tyteca (1996) formulates this index based on the earlier specification by Färe et al (1989), with such additional modification that the value of the index lies between 0 and 1. Unlike the earlier index developed by Färe et al. (1989), Tyteca (1996) derives three different environmental performance indexes directly from three varied formulations, namely, Undesirable Output-oriented (UO) model, Input Undesirable Output-oriented (IUO) model and Normalized Undesirable Output-oriented (NUO) model. Among these three different DEA formulations, the NUO model is particularly appropriate and relevant for this study. The authors' decision to adopt this particular DEA model is justifiable on two basic grounds. First, data on the production inputs of the sampled oil and gas companies is inaccessible. Second, this formulation is the closest to the techniques employed by some studies (for instance, Jaggi and freedman, 1992; Patten, 2002; Al-Tuwaijri et al. 2004) to measure environmental performance in the core literature of this research.

\subsection{Measurement of environmental disclosure}

Corporate environmental reporting as a system of communicating environmental information to the relevant stakeholders is usually operationalized via corporate environmental disclosure (see, Freedman \& Wasley 1990, van Staden \& Hooks 2007, Beck et al. 2010). Freedman \& Wasley (1990) point out that when examining 
the association between environmental performance and disclosure, the two variables must be quantitatively operationalized. Studies concerned with examining the link between firms' environmental performance and disclosure have devised some means of quantitatively measuring the disclosure (see, Ingram \& Frazier 1980, Wiseman 1982, Freedman \& Jaggi 1982, Hughes et al. 2001, Patten 2002, Clarkson et al. 2008, and Dawkins \& Fraas 2011b). Moreover, most of these studies rely on archival reporting medium in order to quantify the variable. The predominant methodology they employed for this purpose is invariably content analysis. Content analysis is the most common method used to quantitatively measure environmental disclosure. Many studies have employed different variations of content analysis for this purpose. Content analysis enables the evaluation of the nature, substance, volume or compliance level of a document's content, or some combination of the aforementioned (Holsti 1969, in Beck et al. 2010, Ingram \& Frazier 1980, Gray et al. 1995, Krippendorff 2004). Smith (2003) describes content analysis as a technique employed to derive meaningful inferences from texts in a document based on a predetermined set of criteria. That content analysis is rigorously developed, widely used and a very useful method of measuring environmental disclosure is well documented in the literature (see, Campbell 2000, Beck et al. 2010). Thus, such techniques as meaning oriented, nature oriented, compliance oriented and volumetric content analysis have been developed. Researchers may choose to modify and use any of these techniques given the unique nature of one's study.

\subsection{Relation between environmental performance and disclosure: theory, prior studies and hypotheses}

Two competing theories, namely legitimacy theory and voluntary disclosure theory, are widely employed in the literature to underpin the relation between environmental performance and disclosure. While legitimacy theory is used to provide an explanation for the negative relation between environmental performance and disclosure, voluntary disclosure is used to offer an explanation when a positive relation is documented.

\subsubsection{Voluntary disclosure theory and the positive association between environmental performance and disclosure}

The idea behind voluntary disclosure theory emanates from the circumstances that inform managers' decision to release nonproprietary information (Dye 1985, Li et al. 1997). Nonproprietary information is described as information whose disclosure depends entirely on the management's discretion (Dye, 1985). As the management has absolute discretion over the release of this kind of information, it is reasonable to assume that the information will only be released if the reporting corporation benefits from such disclosure. In the context of environmental accountability, studies use this theory to underpin positive relation between environmental performance and disclosure (Al-Tuwaijri et al. 2004, Clarkson et al. 2008, and Dawkins \& Fraas 2011a, 2011b). In this regard, Li et al. (1997) contend that firms withhold adverse environmental news, but disclose favorable environmental information. The motive behind this disclosure practice is the possible economic benefit that may be gained by either its disclosure or nondisclosure. Consequently, the theory predicts positive relation between environmental performance and disclosure. Thus, this theory suggests that good environmental performers will always tend to increase the disclosure of environmental information to showcase their good behavior while poor environmental performers will tend to reduce the disclosure of environmental information; for increased disclosure may portray them in bad light (Al-Tuwaijri et al. 2004, Clarkson et al. 2008, Dawkins \& Fraas 2011a, 2011b).

Although, researchers in the literature attribute the essence of this theory to economic benefit (Dye 1985, Li et al. 1997, Clarkson et al. 2008), we contend that the theory may be used to explain firms' environmental reporting practices in less-developed countries in a different context. It is argued that economic growth fueled by in- dustrialization and technological inventions is encouraged without giving much regard to environmental consequences, when an economy is struggling to grow "presumably on the assumption that," stated Arrow et al. (1995, p. 91) "these consequences would either take care of themselves spontaneously or could be dealt with separately." It is clear that less-developed economies give more priority to industrial growth and pay little or no attention to the negative environmental impacts of such growth. By extension, in as much as most stakeholders are more concerned about improving their standard of living, they may most likely not care much whether corporations have adequately provided disclosure about their environmental activities or not. Consequently, corporations operating in less-developed economies will tend to use this opportunity to disclose more environmental information when their environmental performance is better and disclose little or abstain from disclosing altogether, if their environmental performance is poor. Following this scenario, this study holds the view that in lessdeveloped countries where disclosure of environmental information is discretionary (Disu \& Gray 1998), the relationship between environmental performances and the level of environmental disclosure by firms is most probably positive, and the most likely theory underpinning this relationship is VDT. Therefore, since two forms of environmental disclosures are covered in this paper, we specifically hypothesize that:

\section{Either}

H1a: gas-flaring-related environmental performance is positively associated with volumetric disclosure of gas flaring-related information by dominant companies in the Nigerian upstream sector.

Or

$\mathrm{H} 1 \mathrm{~b}$ : gas-flaring-related environmental performance is positively associated with disclosure substance of gas flaring-related information of dominant companies in the Nigerian upstream sector.

\subsubsection{Legitimacy theory and the negative association between environmental performance and disclosure}

In general, legitimacy theory postulates that an organization enjoys the approval of the conferring public within the society if its system's value is consistent with that of the society (Dowling \& Pfeffer 1975, Lindlom 1994). In the context of corporate environmental accountability, legitimacy theory proposes a negative relationship between firm's environmental performance and its environmental disclosure (Patten 1992, Deegan \& Rankin 1996, Hughes et all. 2001, Patten 2002, O'Donovan 2002, Cho \& Patten 2007, Cho et al. 2010). This theory postulates that a corporation faces the danger of legitimacy withdrawal by its conferring stakeholders, if it performs poorly with respect to abatement of environmental damages. To change the intent of the conferring stakeholders not to withdraw the legitimacy, the entity adopts imagerepairing strategy (Limdblom 1994; Gray et al. 1995), and communicates this strategy to the society through increased environmental disclosure. Simply put, an organization that scores low on environmental performance attempts to manage the poor performance via increased environmental disclosures aimed at swaying the conferring public attention away from the poor performance, educating them about the poor performance, or changing their perception altogether (Gray et al. 1995).

Consistent with LT, a number of empirical studies have documented evidence of an inverse relation between environmental performance and disclosure. For instance, Hughes et al (2001) find that environmental performance and disclosure of firms are negatively related. The authors reach this conclusion by empirically establishing that poor environmental performers provide more extensive environmental disclosures than good performers. Similarly, relying on 131 US companies Patten (2002), reports a significant negative relation between environmental performance and disclosure of firms on the premise of legitimacy theory. Likewise, Cho, et al. (2006) indirectly via the variable, political strategy, establish that environmental performance and disclosure are negatively related. Thus, the author's document those poor environmental performers tend to obscure this reality by providing extensive environmental 
disclosure and attempt to use political strategy to block the passage of environmentally friendly legislations. In a similar vein, using two-sample t-test for mean differences, Cho \& Patten (2007) find that consistent with legitimacy theory; environmental performance and disclosure are negatively related. The authors derive this conclusion from their documented evidence that poor environmental performers disclose more environmental information with respect to both monetary and non-monetary non-litigation environmental information than better performers. Clarkson et al. (2011) also report a significant negative relationship between environmental performance and both the extent and nature of environmental disclosure. Finally, de Villier \& van Stadden (2011) find that firms with environmental crisis disclosed more environmental information on their web sites. Moreover, the authors document that firms with poor environmental reputation disclose more environmental information in their annual reports. Certainly, the two findings imply negative association between the two measures of environmental performance and volume of environmental disclosure.

To the best of the authors' knowledge, there has never been any research that empirically examines the relation between environmental performance and disclosure of firms in a less developed country. Obviously, the absence of any empirical research in this context can be attributed to nonexistence of any agency that rates the social and environmental performance of firms operating in less-developed countries and keeps a database of such. This is why most studies on environmental accountability in less-developed countries focus on the environmental disclosure aspect only while ignoring the environmental performance part (see, for instance, Ahmad, 2004, de Villier \& van Staden 2006, Choi 1998, Siddiqui 2001, Ahmad et al. 2003, Rahman et al. 2009, Sumiani et al. 2007, Elijido-Ten 2011). Nonetheless, some of these studies have used LT theory to explain environmental reporting behavior of firms in less-developed countries. For instance, de Villier \& van Staden (2006) document decreases in environmental disclosures of firms operating in South Africa, after an initial increase. The authors attempt to explain the subsequent decrease, arguing that firms will adjust their disclosure either way to legitimize their activities. The authors conclude on this without examining the influence of other factors, especially environmental disclosure, on environmental disclosure. Similarly, Mahadeo et al. (2011) uses Suchman's legitimacy framework to explain the increased social and environmental reporting practices of listed companies in Mauritius. These studies serve as evidence that LT theory can be used to underpin environmental reporting of firms in less-developed countries.

Therefore, in line with the previous studies cited in the preceding paragraph, we use legitimacy theory in an attempt to explain gasflaring-related environmental reporting behavior of dominant companies in the Nigerian upstream sector. However, unlike de Villier \& van Staden (2006) we incorporate gas-flaring-related environmental performance and other control variables in our sample. As such, we hypothesize that:

\section{Either}

H2a: Gas-flaring-related environmental performance is negatively associated with volumetric disclosure of gas-flaring-related information by dominant companies in the Nigerian upstream sector.

Or

$\mathrm{H} 2 \mathrm{~b}$ : Gas-flaring-related environmental performance is negatively associated with disclosure substance of gas-flaring-related information of dominant companies in the Nigerian upstream sector.

\section{Methods and Empirical Results}

Table 1: Study Population/Sample

\begin{tabular}{|c|c|c|}
\hline Company & $\begin{array}{l}\text { Operating Arrange- } \\
\text { ment }\end{array}$ & Operator \\
\hline $\begin{array}{l}\text { 1. Shell Petroleum Development } \\
\text { Company Nigeria Ltd (SPDC) }\end{array}$ & JVC & $\begin{array}{l}\text { Royal Dutch } \\
\text { Shell }\end{array}$ \\
\hline $\begin{array}{l}\text { 2. Chevron Nigeria Limited } \\
\text { (CNL) }\end{array}$ & JVC & $\begin{array}{l}\text { Chevron Tex- } \\
\text { aco }\end{array}$ \\
\hline $\begin{array}{l}\text { 3. Mobil Producing Nigeria } \\
\text { Unlimited (MPNU) }\end{array}$ & JVC & ExxonMobill \\
\hline 4. Pan Ocean & JVC & Pan Ocean \\
\hline $\begin{array}{l}\text { 5. Elf Petroleum Nigeria Ltd } \\
\text { (EPNL) }\end{array}$ & JVC & Total \\
\hline $\begin{array}{l}\text { 6. Texaco Overseas Nigeria } \\
\text { Petroleum Company } \\
\text { (TOPCON) }\end{array}$ & JVC & $\begin{array}{l}\text { Chevron Tex- } \\
\text { aco }\end{array}$ \\
\hline $\begin{array}{l}\text { 7. Nigerian Agip Exploration } \\
\text { (AENR) }\end{array}$ & PSC & Eni/Agip \\
\hline $\begin{array}{l}\text { 8. Addax Petroleum Develop- } \\
\text { ment Nigeria Ltd (APDN) }\end{array}$ & PSC & Addax \\
\hline $\begin{array}{l}\text { 9. Nigerian Petroleum Devel- } \\
\text { opment Company LTD. } \\
\text { (NPDC) }\end{array}$ & SRC & NPDC \\
\hline $\begin{array}{l}\text { 10. Esso Exploration \& Produc- } \\
\text { tion Nigeria Deep-water West } \\
\text { (EEPN) }\end{array}$ & PSC & ExxonMobill \\
\hline $\begin{array}{l}\text { 11. Nigerian Agip Oil Company } \\
\text { Ltd. (NAOC) }\end{array}$ & JVC & Eni/Agip \\
\hline \multicolumn{3}{|c|}{$\begin{array}{l}\text { This table presents eleven oil and gas companies that make up the sample of this } \\
\text { study. The table also presents the kind of arrangements under which each of them is } \\
\text { being operated in the country. In addition, the operators of the eleven arrangements are } \\
\text { also shown in the Table. It is also imperative to clarify that the eleven oil and gas } \\
\text { companies in the sample, all of which are registered and incorporated in Nigeria as } \\
\text { private limited companies, are operated by Foreign Multinational Oil Companies } \\
\text { (FMOC). Although, NNPC has major stake in each of these companies, it remains } \\
\text { non-operating working interest owner in all the ventures. This is mainly because the } \\
\text { technical expertise relating to oil and gas prospecting, exploration and production } \\
\text { remains with the FMOCs. }\end{array}$} \\
\hline
\end{tabular}

\subsection{Study sample and data sources}

Upstream sector of the Nigerian oil and gas industry is made up of companies engaged in the exploration and production of crude oil and natural gas as well as transporting these products to various points of sales, refining or further processing. Oil and gas companies in Nigeria may fall under Joint Venture Arrangement (JVA), Production Sharing Arrangement (PSA), Risk Service Arrangement (RSA) or Marginal Oil Fields (MOF). Companies in the first two categories account for over $90 \%$ of the Nigeria's oil and gas production. While almost all the operators of the joint venture companies and the production sharing contracts are FMOCs, most companies operating under the umbrella of RSA, and MOF are small indigenous companies.

To define the sample of this study, two crucial factors are taken into consideration. These factors are: (i) engagement in flaring significant amount of ANG and (ii) availability of oil and gas information. Based on these two factors, the sample of the study is defined such that it captures oil and gas companies responsible for significant share of ANG flaring in the upstream sector, and from which relevant data could be obtained. In order to identify these companies, the NNPC Annual Statistical Bulletins (ASB) is examined. Any company that reported its information on gas flaring and other oil and gas production activities over the period 1997 to 2009 qualifies as a member of the sample. At the end of the exercise, eleven companies are identified as the members of the study sam- 
ple. The eleven companies identified in Table 1, have been responsible for $93.21 \%$ production of crude oil in the upstream sector of the Nigerian oil and gas industry and these companies represent the study sample. Consistent with the principle of time-series crosssection dataset, unlike the traditional panel dataset, the fixed population is the same as the sample (Becks, 2001). The impossibility of re-sampling in the case of this study's sample is the result of the imposition of the condition that for a company to form part of the population, it must have reported its oil and gas-related information in the NNPC's ASB at least once over the thirteen years covered by the study. It is believed that studying these companies' environmental reporting behavior regarding $\mathrm{CO}_{2}$ emission due to gas flaring would provide insight into environmental accountability behavior in the Nigeria's upstream sector.

This study relies on archival secondary data in respect of the relevant variables. The data has been collected from two major sources. These are the NNPC's ASBs and the sampled companies' operators' sustainability reports, CSR reports, annual reports or other similar reports.

\subsubsection{NNPC's annual statistical bulletin (ASB)}

NNPC started reporting specific and quantitative information concerning flaring of ANG by major oil and gas companies operating in the country, arguably in recognition of the importance of this information and the sensitivity of the environmental impact of the wasteful practice globally (Hassan \& Kouhy, 2013). In addition, these companies happen to be the companies in which NNPC has controlling stakes. Annual Statistical Bulletin (ASB) is the NNPC's official reporting medium published yearly, as the name implies, in order to voluntarily report on the activities of the Nigerian oil and gas industry. To the best our knowledge, NNPC's ASB is the most comprehensive publicly available document that provides detailed information regarding both upstream and downstream activities of oil and gas companies in the industry. It reports comprehensively on companies' seismic activities, crude oil production, crude oil lifting, crude oil export, ANG production, ANG utilization, gas transmission and gas export. In the words of NNPC, the essence of publishing ASB is "to give a clear picture of the activities that spell out the major economic profile of Nigeria driving for transparency and accountability". For the purpose of this study we extract data concerning such variables as crude oil produced, ANG produced, ANG utilized and ANG flared from the ASBs for each company in the sample over the thirteen-year period covered. Moreover, since NNPC has the higher stake than any other FMOC in all the eleven Nigerian oil and gas companies in the sample, its disclosure concerning these companies is regarded as part disclosure in respect of the companies in our sample. The other source is, of course, the operators' reports.

\subsubsection{Operators' reports}

Operators' reports are other sources of GFR disclosures that complement the ASB disclosures. Thus, the study relies on any relevant report via which any operator of any company in the sample has made disclosure regarding gas flaring in the upstream sector of the Nigerian oil and gas industry. However, preference for the reports is in the following order. First, the operator's sustainability report is searched for. If it is not available, then annual report is searched for. If the annual report is not available, then other reports such as press release, fact sheets or other forms of web-based reports are relied upon.

\subsection{Measurement of the dependent variable - GFR envi- ronmental disclosure}

This study relies on content analysis to measure GFR environmental disclosure. Specifically, the study relies on two archival sources of GFR information, namely, the ASBs of NNPC and the reports of the FMOCs as the operators of the sampled companies. The operators report gas flaring-related information specific to Nigeria in their stand-alone sustainability reports, annual reports, press releases or fact sheets. Other venturers' reports have not been considered because they are mostly minority non-operating investors in the sampled companies. As such, GFR disclosures from these two sources are integrated to produce two disclosure indexes, which measure the volume and substance of what has been disclosed (Freedman \& Jaggi 2005). Essentially, this study uses two content analysis-based measures of GFR environmental disclosure. The first index, substance disclosure index (SDI), measures the substance of what is disclosed (see, Wiseman 1982, Freedman \& Wasley 1990, Patten 2002, Al-Tuwaijri et al. 2004, Freedman \& Jaggi 2005), while the second index, volumetric disclosure index (VDI), measures the level of what is disclosed based on the number words used to disclose GFR information (see, Zeghal \& Ahmed 1990, Deegan \& Gordon 1996, Campbell 2003, Hassan \& Kouhy 2013).

Therefore, consistent with Zeghal \& Ahmed (1990), Deegan \& Gordon (1996), Campbell (2003) and Hassan \& Kouhy (2013), volume of GFR environmental disclosure is measured using word count. In general, our measurement strategy is similar to that used by Hassan \& Kouhy (2013). However, while Hassan \& Kouhy (2013) use the strategy to measure volumetric disclosure for the whole Nigerian oil and gas industry, we use it in this study to develop volumetric disclosure for individual companies in the industry. Essentially, this version of the disclosure is made up of total number words disclosed relating to gas flaring in both the ASBs and the FMOCs' reports in respect of each company in our sample over period of thirteen years. Words included in the count include all the words used to form sentences, paragraphs, tables and figures that talk about ANG flaring, ANG utilization and carbon emission due to gas flaring. Then consistent with Tyteca (1997), the number of words disclosed in the ASB of a particular year plus the number of words disclosed in the relevant operator's report of the same year is scaled such that the value of the index for each year ranges between 0 and 1 (with 0 denoting the worst score and 1 the best score) using the following formula:

$V D I=\frac{\sum W_{o y}}{\sum W_{i y}}$

Where VDI represents the volume of GFR disclosure (Note that $0 \leq V D I \leq 1)$. $\sum W_{\text {oy }}$ measures the total number of words disclosed in respect of the focused oil and gas company in a specific year in both ASB and operator's report. $\sum W_{i y}$ represents the highest number of words disclosed by an identified company in the sample?

NNPC discloses GFR information in its ASB along with much other oil and gas-related information. Consistent with Clarkson et al. (2008), GFR information disclosed in the ASB is recognized and described as specific and hard disclosure, as these items of information are reported either quantitatively, in specific textual detail or both. Consequently, a company gets a score of 3, if NNPC has reported its GFR information in an ASB of a particular reporting year otherwise 0 . Secondly, with regard to the other aspect of the measurement from the operators report, consistent with Freedman \& Jaggi (2005), the study uses the following disclosure items as they specifically relate to reporting of GFR information for each company in each relevant year:

- Reference to gas flaring;

- Reference to $\mathrm{CO}_{2}$ emission equivalent of gas flared (carbon reduction or increase);

- Reference to existing associated gas utilization projects and

- Reference to planned associated gas utilization Projects.

Then, following Wiseman, (1982), Patten (2002); Al-Tuwaijri et al (2004) the substance of disclosure relating to each item is rated on the basis of whether such disclosure is specific and quantitative, specific non-quantitative or nonspecific. Specific, quantitative disclosure attracts a score of 3; specific non-quantitative disclosure receives 2 points; general non-quantitative disclosure would be graded as 1 and nondisclosure receives 0 . Table 2 below provides details of the disclosure substance rating. Again following Tyteca (1996) final disclosure substance scores for companies in each year are scaled such that the values fall between 0 and 1 as the mini- 
mum and maximum values obtainable, respectively. We call this measure a disclosure substance index following Freedman \& Jaggi (2005).

Table 2: Measurement of GFR disclosure substance

\begin{tabular}{llllll}
\hline $\begin{array}{l}\text { Item of } \\
\text { Disclosure }\end{array}$ & $\begin{array}{l}\text { Specific } \\
\text { Quantitative }\end{array}$ & $\begin{array}{l}\text { Specific } \\
\text { Textual }\end{array}$ & $\begin{array}{l}\text { General } \\
\text { Textual }\end{array}$ & $\begin{array}{l}\text { Non- } \\
\text { disclosure }\end{array}$ & $\begin{array}{l}\text { Max } \\
\text { Score }\end{array}$ \\
\hline $\begin{array}{l}\text { Reporting gas flar- } \\
\text { ing in the ASB }\end{array}$ & - & - & - & - & 3 \\
$\begin{array}{l}\text { Reporting gas flar- } \\
\text { ing }\end{array}$ & 3 & 2 & 1 & 0 & 3 \\
$\begin{array}{l}\text { Reporting CO } \\
\text { equivalent of gas } \\
\text { flaring }\end{array}$ & 3 & 2 & 1 & 0 & 3 \\
$\begin{array}{l}\text { Reporting existing } \\
\text { gas utilisation pro- }\end{array}$ & 3 & 2 & 1 & 0 & 3 \\
jects & & & & & \\
$\begin{array}{l}\text { Reporting of } \\
\text { planned gas utilisa- } \\
\text { tion project }\end{array}$ & 3 & 2 & 1 & 0 & 3 \\
$\begin{array}{l}\text { Total maximum } \\
\text { disclosure score }\end{array}$ & - & - & - & - & 15 \\
\hline
\end{tabular}

\subsection{Measurement of the independent variable - GFR environmental performance}

When developing a DEA environmental technology, the following formulation is generally specified (see, Tyteca 1997, Färe et al. 1996, Zaim 2004, Färe et al. 2004).

Given $n$ independent DMUs, represented by $D M U_{j}(j=$ $1,2,3, \ldots ., n$. Each DMU uses $m$ inputs, denoted by $x_{i j}(i=1,2,3, \ldots, m)$ to produce $s$ desirable outputs denoted by $y_{r j}(r=1,2,3, \ldots, s)$ and emits $u$ undesirable outputs denoted by $b_{k j}(k=1,2,3, \ldots, u)$.

However, in this study, the specification above is modified such that the DMUs are the dominant oil and gas companies operating in the upstream sector of the Nigerian oil gas industry. Therefore, $n$ represents the number of oil and gas companies considered in this study. Two major desirable outputs, crude oil $(\mathrm{CO})$ and ANG utilized $(G U)$ are produced by the companies in the sample. This study is concerned with an important undesirable production output, namely carbon dioxide equivalent of gas flared $(C E)$. Consequently, following the production technology $(P T)$ is stated as follows:

$\mathrm{PT}=\{(\mathrm{x}, \mathrm{CL}, \mathrm{GU}, \mathrm{CE}): \mathrm{x}$ can produce $(\mathrm{CO}, \mathrm{GU}, \mathrm{CE})\}$

In the context of theory of productive efficiency, $P T$ is assumed to be closed and bounded production set, and that desirable production outputs are freely disposable (Tyteca 1996, Zhou et al. 2009). The former assumption implies that determinate amount of production input ( $x$, in this study) can produce limited amount of desirable outputs (CU and GU) and pollutants (CE).

Importantly, moreover, this production technology exhibits 'nulljointness' and 'weak disposability' properties (Färe et al. 2004, Zaim 2004, and Zhou et al. 2009). Thus, the nulljointness and weak disposability assumptions specific to environmental DEA model formulation in this research are stated as follows:

i. If $(\mathrm{x}, \mathrm{CO}, \mathrm{GU}, \mathrm{CE}) \in \mathrm{PT} \& C E=0$, then $C O=0, G U=0$. This represents the nulljointness assumption and it shows the impossibility of producing $\mathrm{CO} \& \mathrm{GU}$ without producing $\mathrm{CE}$.

ii. If $(\mathrm{x}, \mathrm{CO}, \mathrm{GU}, \mathrm{CE}) \in \mathrm{PT} \& 0<\theta \leq$

1 , then $(x, \theta C O, \theta G U, \theta C E) \in$ PT. This represents the weak disposability property which accounts for the costs that an oil and gas company incurs as a result of emitting the undesirable outputs (CE).

The production technology specified in (5) can be restated in the format of Shepherd (1970) distance function for the sub-vector of bad outputs, $C E$ in our case, as follows:

$D_{C E} \equiv(C O, G U, C E)=\operatorname{Max}\left\{\phi:\left(C O, G U, \frac{C E}{\phi}\right) \in P T\right\}$

However, this distance function $\left(D_{C E}\right)$ would lead to the formulation of non-linear programming problem. Since, the above distance function is related to the output oriented model, its input oriented equivalent can be used to construct a distance function that would enable the formulation of linear programming problem. Note that the relationship between the input and the output oriented DEA models (see, Cooper et al, 2007), when productive efficiency is optimal, is:

$\theta=1 / \phi$

Therefore, based on (7) the following Shepherd (1970) input distance function is equivalent to (6) above (based on the fact that $\left(\frac{\mathrm{GF}}{\phi}=\theta \mathrm{GF}\right)$

$\mathrm{D}_{\mathrm{CE}} \equiv(\mathrm{OL}, \mathrm{GU}, \mathrm{GF})=\operatorname{Min}\{\theta:(\mathrm{OL}, \mathrm{OG}, \theta \mathrm{GF},) \in \mathrm{T}\}$

And, this can be modeled as a linear programming problem, in a piece-wise fashion as in Zhou et al. (2009) as follows: $\min _{\theta, \lambda} \theta=\mathrm{CEP}$

Subject to

$\mathrm{CO}_{\mathrm{o}}-\sum_{\mathrm{j}=1}^{\mathrm{n}} \lambda_{\mathrm{j}} \mathrm{CO}_{\mathrm{j}} \leq 0$

$\mathrm{GU}_{\mathrm{o}}-\sum_{\mathrm{j}=1}^{\mathrm{n}} \lambda_{\mathrm{j}} \mathrm{GU}_{\mathrm{j}} \leq 0$

$\theta C E_{o}-\sum_{j=1}^{n} \lambda_{j} C_{j}=0$

$\lambda_{\mathrm{j}} \geq 0, \quad \theta \geq 0, \quad \mathrm{j}=1,2,3, \ldots, \mathrm{n}$

Where:

$\theta(\theta=\mathrm{CEP})=$ Environmental performance index

$\lambda=$ Intensity variable (Note: at optimum efficiency $\lambda=\theta=1$ )

$\mathrm{CO}_{\mathrm{o}}=$ Volume of crude oil produced by the focused oil and Gas Company in the sample

$\mathrm{CO}_{\mathrm{j}}=$ Volume of crude oil produced by other oil and gas companies in the sample

$\mathrm{GU}_{\mathrm{o}}=$ Volume of ANG utilised by the focused oil and Gas Company

$\mathrm{GU}_{\mathrm{j}}=$ Volume of ANG utilised by each of all the other oil and gas companies

$\mathrm{CE}_{\mathrm{o}}=$ Kilogram of $\mathrm{CO}_{2}$ emitted due to gas flaring by the focused oil and Gas Company

$\mathrm{CE}_{\mathrm{o}}=$ Kilogram of $\mathrm{CO}_{2}$ emitted due to gas flaring by all other oil and gas companies.

Färe et al. (1989) formulate a DEA model which permits asymmetric relationship between desirable and undesirable production outputs. The main DEA model of this study is formulated by making a slight modification to (9). The modification takes the form of treating carbon emission due to ANG flaring (CE), measured in a kilogram of $\mathrm{CO}_{2}$ and ANG utilized (GU) measured in cubic meters asymmetrically. This implies that an increase in the volume of GU leads to a proportionate decrease in $\mathrm{CO}_{2}$ emitted as a result of flaring ANG (GF). The reverse also holds true. Indeed, this model is consistent with all the gas flaring reduction policies, regulations, agreements being employed in Nigeria. They invariably aim at increasing the economic benefit of utilizing the ANG and reducing its waste as well as environmental pollution in the form of $\mathrm{CO}_{2}$ emission.

The asymmetric form of the Shepherd (1970) input distance function for the sub-vector of $\mathrm{CO}_{2}$ emitted as a result of gas flaring $(G F)$ is given by:

$\mathrm{D}_{\mathrm{GF}}(\mathrm{CO}, \mathrm{GU}, \mathrm{CE})=\min \left\{\theta:\left(\mathrm{CO}, \frac{1}{\theta} \mathrm{GU}, \theta \mathrm{CE},\right) \in \mathrm{PT}\right\}$

This distance function results in the formulation of the following non-linear programming problem:

$\min _{\theta, \lambda} \theta=\mathrm{CEP}$

Subject to:

$\mathrm{CO}_{\mathrm{o}}-\sum_{\mathrm{j}=1}^{\mathrm{n}} \lambda_{\mathrm{j}} \mathrm{CO}_{\mathrm{j}} \leq 0$

$\frac{1}{\theta} \mathrm{GU}_{\mathrm{o}}-\sum_{\mathrm{j}=1}^{\mathrm{n}} \lambda_{\mathrm{j}} \mathrm{GU}_{\mathrm{j}} \leq 0$

$\theta C E_{o}-\sum_{j=1}^{n} \lambda_{j} C E_{j}=0$

$\lambda_{\mathrm{j}} \geq 0, \quad \mathrm{j}=1,2,3, \ldots, \mathrm{n}$

Following Färe et al. (1989) the non-linear constrain $\left(\frac{1}{\theta} G U_{o}-\right.$ $\left.\sum_{j=1}^{n} \lambda G U_{j} \leq 0\right)$ is replaced with its linear equivalent $\left(2 G U_{o}-\right.$ $\left.\theta G U_{o}-\sum_{j=1}^{n} \lambda G U_{j} \leq 0\right)$. Consequently, the model takes the following linear programming form:

$\min _{\theta, \lambda} \theta=$ CEP

Subject to: 
$\mathrm{CO}_{\mathrm{o}}-\sum_{\mathrm{j}=1}^{\mathrm{n}} \lambda_{\mathrm{j}} \mathrm{CO}_{\mathrm{j}} \leq 0$

$2 \mathrm{GU}_{\mathrm{o}}-\theta \mathrm{GU}_{\mathrm{o}}-\sum_{\mathrm{j}=1}^{\mathrm{n}} \lambda_{\mathrm{j}} \mathrm{GU}_{\mathrm{j}} \leq 0$

$\theta C E_{o}-\sum_{j=1}^{n} \lambda_{j} C E_{j}=0$

$\lambda_{\mathrm{j}} \geq 0, \quad \mathrm{j}=1,2,3, \ldots, \mathrm{n}$

$\theta(\theta=$ CEP $)=$ Gas flaring-related environmental performance index

$\lambda=$ Intensity variable (Note: at optimum efficiency $\lambda=1$ )

$\mathrm{CL}_{\mathrm{o}}=$ Volume of crude oil produced by the focused oil and Gas Company in the sample.

$\mathrm{CL}_{\mathrm{j}}=$ Volume of crude oil produced by $\mathrm{j}$ oil and gas companies in the sample

$\mathrm{GU}_{\mathrm{o}}=$ Volume of ANG utilised by the focused oil and Gas Company

$\mathrm{GU}_{\mathrm{j}}=$ Volume of ANG utilised by each of all the other oil and gas companies

$\mathrm{CE}_{\mathrm{o}}=$ Kilogram of $\mathrm{CO}_{2}$ emitted due to gas flaring by the focused oil and Gas Company

$\mathrm{CE}_{\mathrm{j}}=$ Kilogram of $\mathrm{CO}_{2}$ emitted due to gas flaring by all other oil and gas companies

The study refers to model (12) as Asymmetric Normalized Undesirable Output (ANUO) DEA model, and uses it used to develop GFR environmental performance indexes (CEP) for the companies in the study's sample.

\subsection{Time-series cross-section analysis}

The study relies on Praise-Winsten regression with Panel Corrected Standard Errors (PCSEs) to analyze the pooled time-series crosssection (TS-CS) dataset compiled in this study. The use of this TSCS regression modeling is justified on the ground that the pooled dataset is relatively small (eleven oil and gas companies studied over thirteen years). Unlike Generalized Least Squares (GLS) PCSEs performs efficiently even with small sample (Beck \& Karz 1995, 1996, Beck 2001). Beck \& Katz (2007) describe TS-CS dataset as being made up of temporal observations collected at regular intervals, usually annual, on fixed units (for example, OPEC members or OECD members). Beck (2001) points out that TC-CS data is different from panel data in that in the case of TSCS dataset, large sample properties are associated with the repeated observations and not the cross-sections or units which are assumed to be fixed. The nature of the dataset collected in this study is described as follows:

- The units are the dominant oil and gas companies whose data on gas flaring, gas utilization and oil production are available in the NNPC annual statistical bulletins.

- Over the period covered by the study, NNPC reported the required data for only 11 companies.

- The 11 companies represent the population which is also the sample of the study. Consequently, re-sampling is impossible. The number of companies is fixed at 11 .

- The time period is annual and relevant data was collected over 13 years (1997-2009).

- Therefore, it follows that the dimension of the dataset is $\mathrm{N}=11$, $\mathrm{Y}=13$.

- Consistent with definition of finite (small) time-series crosssection data as in Beck (2001), Beck \& Katz (2007) and Podestà (2006), our dataset qualifies as such.

Panel Corrected Standard Errors (PCSEs) modeling involves using Ordinary Least Squares (OLS) or Prais-Winsten regression to estimate linear TS-CS models with panel-based corrected standard errors (Beck \& Karz 1995, 1996, Plümper et al. 2005). In this study, PCSEs is used to estimates two models. The first model focuses on estimating the association between gas flaring-based environmental performance (CEP) on one hand, and volumetric environmental disclosure (VDI) on the other hand. More specifically, the first model estimates and measures the effect of CEP on VDI while controlling for such variables as size, gas price and company type.

$\mathrm{VDI}_{\text {it }}=\beta_{0}+\beta_{1} \mathrm{CEP}_{\mathrm{it}}+\beta_{2} \mathrm{LOG}_{\mathrm{CO}_{\text {it }}}+\beta_{3} \mathrm{GPR}_{\mathrm{it}}+u_{\mathrm{it}}$
Essentially, the aim of this model is to facilitate testing of the first hypothesis ( $\mathrm{H} 1 \mathrm{a}$ or $\mathrm{H} 1 \mathrm{~b})$. The second model focuses on estimating the relationship between CEP and SDI, while controlling for the influence of company size (CO), environmental philosophy (GOR), natural gas price (GPR) and investment in gas utilization (GUI) projects.

$\mathrm{SDI}_{\text {it }}=\beta_{0}+\beta_{1} \mathrm{CEP}_{1 \mathrm{it}}+\beta_{2} \mathrm{LOG}_{\mathrm{CO}_{\text {it }}}+\beta_{3} \mathrm{GOR}_{\text {it }}+\beta_{4} \mathrm{GPR}_{\text {it }}+$

$\beta_{5} \mathrm{GUI}_{\mathrm{it}}+u_{\mathrm{it}}$

The model is used to test the second hypothesis ( $\mathrm{H} 2 \mathrm{a}$ or $\mathrm{H} 2 \mathrm{~b})$.

\section{Empirical results}

Because results documented in respect of the relation between CEP on one hand and VDI and SDI on the hand are significantly positive and negative respectively, we drop $\mathrm{H} 1 \mathrm{~b}$ and $\mathrm{H} 2 \mathrm{a}$. We, therefore, focus on $\mathrm{H} 1 \mathrm{a}$ and $\mathrm{H} 2 \mathrm{~b}$. In this context, it is imperative to draw the attention of the reader to the fact that the four hypotheses of the study are formulated such that only two out of the four would be tested and hence relevant for empirical analysis.

\subsection{CEP and VDI relationship: test of hypothesis one}

In order to evaluate the relationship between CEP and VDI, TS-CS data is assembled in respect of the two variables. Apart from these two major variables of interest, data in respect of two other variables (LOG_CO and GPR) used in the model as control variables have also been pooled for the eleven oil and gas companies over the relevant period

Table 3: Summary of variables' descriptive statistics in the model of VDICEP relationship

\begin{tabular}{l|rrrrr}
\hline Variables & Mean & St.Dev & Median & Max. & Min. \\
\hline VDI & 0.2645 & 0.2401 & 0.2053 & 1.0000 & 0.0370 \\
CEP & 0.3292 & 0.2589 & 0.2803 & 1.0000 & 0.0030 \\
LOG_CO & 17.3712 & 1.7881 & 17.7391 & 19.7240 & 7.8482 \\
GPR (in \$) & 5.0906 & 2.2412 & 4.4300 & 9.0000 & 1.9700 \\
$\mathrm{~N}$ & & & 143 & & \\
\hline
\end{tabular}

Table 3 presents the descriptive statistics in respect of the relevant variables in the TS-CS regression model (13). In essence, Table 3 is presented in order to give the reader a feel of the dataset. In order to estimate an efficient TC-CS regression model two steps are followed. First, based on traditional panel analysis, the dataset is used to estimate a fixed effect model based on which diagnostic tests are conducted (see, Table 4). And, then based on the outcomes of the diagnostic tests a more consistent TS-CS regression model is estimated (see, Table 5).

Table 4 presents the fixed effect model which estimates the relationship between CEP and VDI. This model is estimated and presented to subject the TS-CS dataset to five diagnostic tests (company specific fixed effect, time fixed effect, panel heteroskedasticity, contemporaneous correlation and panel autocorrelation) usual with this type of data. It can be seen from Table 4 that all the five diagnostic tests are significant, and this indicates that the traditional diagnostic tests' null hypotheses for the absence of the problems being diagnosed are rejected. Therefore, we estimate a more efficient model that corrects for all the problems in Table 5. 
Table 4: Model Ia: exploratory fixed effect model and diagnostics tests. $\mathrm{VDI}_{\mathrm{it}}=\beta_{0}+\beta_{1} \mathrm{CEP}_{\mathrm{it}}+\beta_{2} \mathrm{LOG}_{-} \mathrm{OL}_{\mathrm{it}}+\beta_{3} \mathrm{GPR}_{\mathrm{it}}+u_{\mathrm{it}}$

\begin{tabular}{|c|c|c|c|}
\hline $\begin{array}{l}\text { Dependent Variable: VDI } \\
\text { Independent Variable: }\end{array}$ & Coefficient. & Standard Error & $\begin{array}{r}\text { t-stat } \\
\& \text { Prob. }\end{array}$ \\
\hline$C E P$ & 0.049 & 0.116 & $\begin{array}{r}0.42 \\
(0.672)\end{array}$ \\
\hline$L O G \_C O(S I Z E)$ & -0.008 & 0.019 & $\begin{array}{r}-0.44 \\
(0.663)\end{array}$ \\
\hline$G P R$ & 0.024 & 0.008 & $\begin{array}{l}3.01 * * \\
(0.003)\end{array}$ \\
\hline INTERCEPT & 0.275 & 0.324 & $\begin{array}{r}0.85 \\
(0.399) \\
\end{array}$ \\
\hline \multicolumn{4}{|l|}{ Model fit \& diagnostic tests } \\
\hline R-Squared & & & $9.08 \%$ \\
\hline \multirow{2}{*}{ Overall Model F-Test } & F-stat & & $3.33^{*}$ \\
\hline & Prob. & & $(0.0226)$ \\
\hline \multirow{2}{*}{$\begin{array}{l}\text { Joint F-test for units fixed } \\
\text { effect }\end{array}$} & F-stat. & & $5.28 * * *$ \\
\hline & Prob $>$ F & & $(0.0000)$ \\
\hline \multirow{2}{*}{ Joint F-test for time fixed effect } & F-stat. & & $2.01^{*}$ \\
\hline & Prob $>$ F & & $(0.0307)$ \\
\hline \multirow{2}{*}{$\begin{array}{l}\text { Breusch-Pagan LM test of } \\
\text { cross-sectional dependence }\end{array}$} & Chi2 & & $103.5^{* *}$ \\
\hline & Prob. & & $(0.0001)$ \\
\hline \multirow{2}{*}{$\begin{array}{l}\text { Wald test for group-wise panel } \\
\text { heteroskedasticity }\end{array}$} & $\mathrm{Chi}^{2}$ & & $1321 * * *$ \\
\hline & Prob $>$ chi 2 & & $(0.0000)$ \\
\hline \multirow{2}{*}{$\begin{array}{l}\text { Wooldridge test for autocorre- } \\
\text { lation in panel data }\end{array}$} & F-stat. & & $5.30^{*}$ \\
\hline & Prob. $>\mathrm{F}$ & & $(0.0468)$ \\
\hline
\end{tabular}

Estimated autoregressive coefficient from AR(1) model $\rho$ 0.575

Asterisks are used to indicate significance as follows: $*=$ Significant at $5 \%$; ** $=$ Significant at $1 \%$ and $* * *=$ Significant at $0.1 \%$. Probabilities and degrees of freedom are reported within parentheses.

Table 5: Model Ib - Prais-Winsten regression with panel corrected standard errors, unit fixed effect $\&$ time fixed effect $\mathrm{VDI}_{\mathrm{it}}=\beta_{0}+\beta_{1} \mathrm{CEP}_{\mathrm{it}}+\beta_{2} \mathrm{LOG}_{-} \mathrm{CO}_{\mathrm{it}}+\beta_{3} \mathrm{GPR}_{\mathrm{it}}+\mathrm{V}_{\mathrm{i}}+\Upsilon_{\mathrm{t}}+u_{\mathrm{it}}$

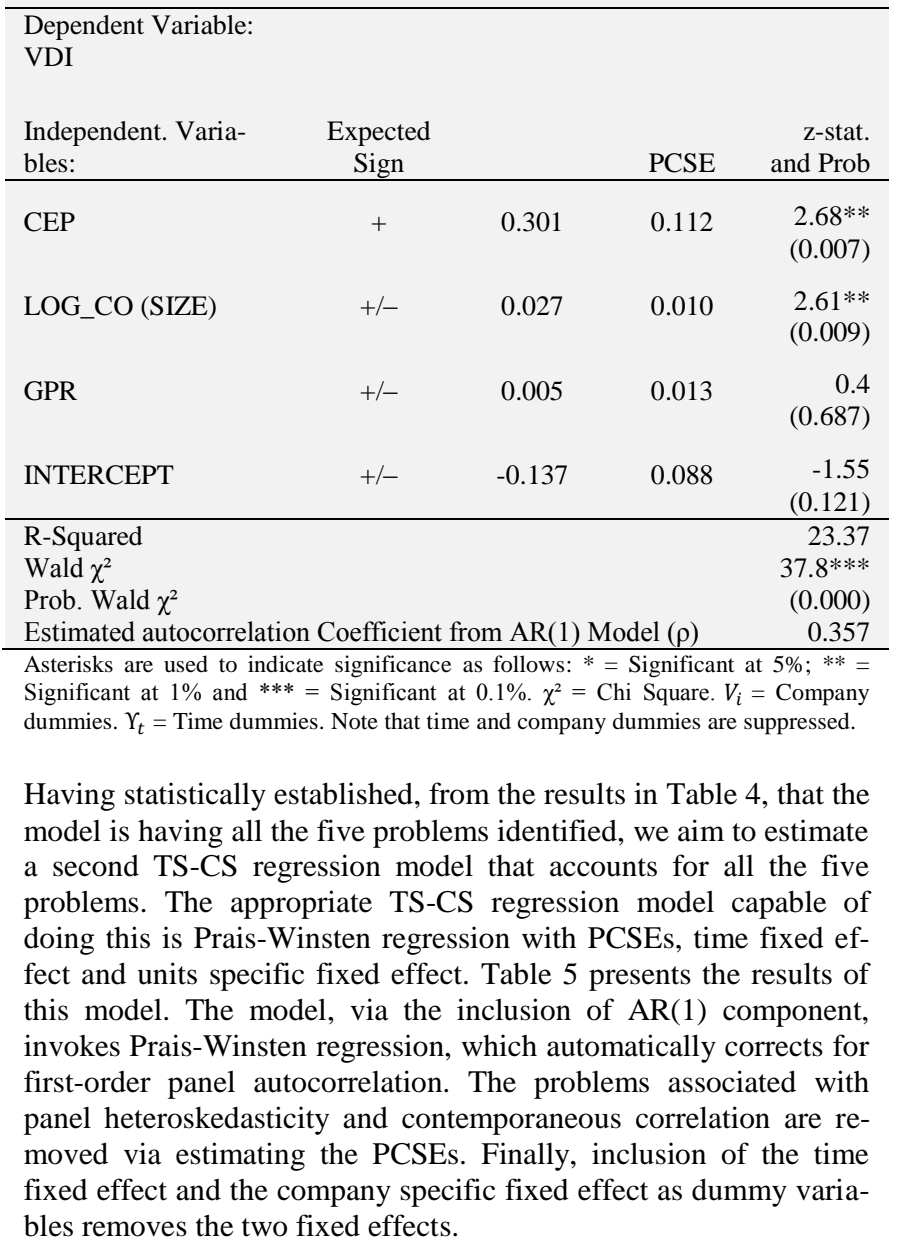

To test H1a, attention is focused on that aspect of the results presented in Table 5 which estimates the effect of CEP on VDI. H1a, restated in its null form, predicts that: Gas-flaring-related environmental performance does not have significant positive impact on the volumetric disclosure of gas-flaring-related information. The results in Table 5 shows that the probability (0.007) associated with the z-statistic (2.68) regarding the coefficient of CEP being different from zero are less than $1 \%$ level of significance. This implies that the null hypothesis can be rejected and it can be concluded with very strong conviction that GFR environmental performance and GFR volumetric environmental disclosure are significantly positively related. This result is consistent with the conclusion reported by Al-Tuwaijri et al. (2004), Clarkson et al (2008) \& Dawkins and Frass (2011b), and support the theoretical proposition of voluntary disclosure theory (see, Verrachia 1983, Dye 1985, Bewley \& Li 2000).

\subsection{CEP and SDI relationship: test of hypothesis two}

As we performed in the previous section, to investigate the nature of the relationship between CEP and SDI, TS-CS dataset have been collated and organized regarding the two variables. In addition, data in respect of four other control variables (LOG_CO, GOR, GPR and GUI) are assembled and included in the model. To acquaint the reader with the dataset, descriptive statistics regarding the six variables in the model are provided in Table 6.

Table 6: Descriptive Statistics for Variables in the Model II

\begin{tabular}{llllll} 
Variable & Mean & St.Dev. & Median & Max & Min \\
\hline SDI & 0.362 & 0.280 & 0.192 & 1.000 & 0.088 \\
CEP & 0.329 & 0.259 & 0.280 & 1.000 & 0.003 \\
LOG_CO & 17.37 & 1.79 & 17.74 & 19.72 & 7.85 \\
GOR & 656.05 & 1363.59 & 367.53 & 14428.92 & 66.41 \\
GPR & 5.09 & 2.24 & 4.43 & 9.00 & 1.97 \\
GUI & 2.78 & 14.80 & 0.36 & 94.87 & 0.003 \\
N & & & 143 & & \\
\hline
\end{tabular}

Again, as we performed in section 4.1, two-step-approach is employed in order to estimate the appropriate TS-CS regression model on the relation between CEP and SDI. Firstly, the TS-CS dataset is subjected to relevant diagnostic tests after estimating the fixed effect model presented in Table 7. Secondly, based on the results of the diagnostic tests a consistent TS-CS regression model is estimated and presented in Table 8 .

Out of the five diagnostic tests only joint F-test for time fixed effect is not significant. Hence, the null hypothesis for no time fixed effect cannot be rejected. However, it can be seen from the table that the other four diagnostic tests as reported are significant. This means that the model suffers from all the four problems diagnosed.

Table 7: Mode IIa Exploratory Fixed Effect Model and Diagnostics Tests $\mathrm{SDI}_{\text {it }}=\beta_{0}+\beta_{1} \mathrm{CEP}_{\text {it }}+\beta_{2} \mathrm{LOG}_{-} \mathrm{CO}_{\text {it }}+\beta_{3} \mathrm{GOR}_{\text {it }}+\beta_{4} \mathrm{GPR}_{\text {it }}+\beta_{5} \mathrm{GUI}_{\text {it }}+u_{\text {it }}$

\section{Dependent Variable: SDI}

Independent Variables $\quad$ Expected Coefficient t-stat. \&

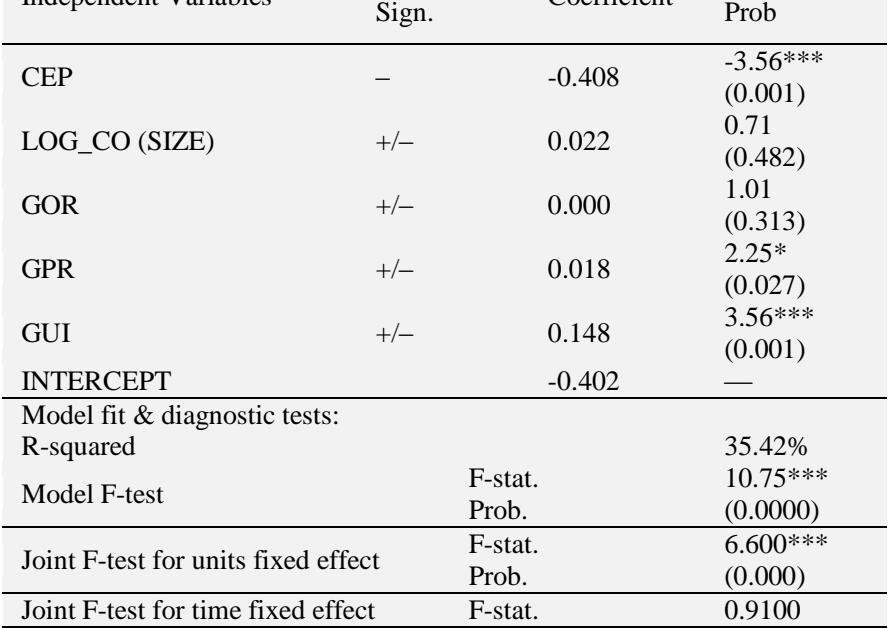




\begin{tabular}{lll}
\hline & Prob. & $(0.541)$ \\
\hline Breusch-Pagan LM test for panel & Chi2 & $85.548^{* *}$ \\
independence & Prob. & $(0.005)$ \\
\hline Wald test for group-wise/panel & Chi2 & 405.28 \\
heteroskedasticity & Prob. & $(0.000)$ \\
Wooldridge test for autocorrelation & F-stat. & $36.855^{* * *}$ \\
in panel data & Prob. & $(0.000)$ \\
Estimated autocorrelation coefficient from AR(1) Model & 0.9985 \\
\hline Asterisks are used to indicate significance as follows: * = Significant at \\
5\%; ** Significant at 1\% and *** = Significant at 0.1\%. Probabilities and \\
degrees of freedom are reported within parentheses.
\end{tabular}

Table 8: Model Ilb Prais-Winsten Regression with Panel Corrected Standard Errors and Unit Fixed Effect

\begin{tabular}{|c|c|c|c|c|}
\hline \multicolumn{5}{|c|}{$\begin{array}{c}\mathrm{SDI}_{\mathrm{it}}=\beta_{0}+\beta_{1} \mathrm{CEP}_{1 \mathrm{it}}+\beta_{2} \mathrm{LOG}_{-} \mathrm{OL}_{\mathrm{it}}+\beta_{3} \mathrm{GOR}_{\mathrm{it}}+\beta_{4} \mathrm{GPR}_{\mathrm{it}}+\beta_{5} \mathrm{GUR}_{\mathrm{it}} \\
+\mathrm{V}_{\mathrm{i}}+u_{\mathrm{it}}\end{array}$} \\
\hline $\begin{array}{l}\text { Dependent Variable: } \\
\text { SDI Independent Varia- } \\
\text { bles: }\end{array}$ & $\begin{array}{l}\text { Expected } \\
\text { Sign. }\end{array}$ & Coeff. & PCSE & $\begin{array}{l}\text { t-stat \& } \\
\text { Prob. }\end{array}$ \\
\hline CEP & - & -0.405 & 0.111 & $\begin{array}{l}-3.38 * * * \\
(0.001)\end{array}$ \\
\hline LO”G_CO (SIZE) & $+1-$ & 0.014 & 0.017 & $\begin{array}{l}0.81 \\
(0.418)\end{array}$ \\
\hline GOR & $+1-$ & 0.000 & 0.000 & $\begin{array}{l}1.32 \\
(0.187)\end{array}$ \\
\hline GPR & $+1-$ & 0.015 & 0.006 & $\begin{array}{l}2.37 * \\
(0.018)\end{array}$ \\
\hline GUI & $+1-$ & 0.099 & 0.039 & $\begin{array}{l}2.55^{*} \\
(0.011)\end{array}$ \\
\hline INTERCEPT & $+1-$ & -0.133 & 0.287 & $\begin{array}{l}-0.46 \\
(0.642)\end{array}$ \\
\hline R-squared & & & & $59.21 \%$ \\
\hline Wald $\chi^{2}$ & & & & $2024 * * *$ \\
\hline Prob. Wald $\left(\chi^{2}\right)$ & & & & $(0.000)$ \\
\hline Estimated autocorrelatic & oefficient & $\mathrm{AR}(1$ & & 0.390 \\
\hline
\end{tabular}

Asterisks are used to indicate significance as follows: $*=$ Significant at $5 \% ; * *=$ Significant at $1 \%$ and $* * *=$ Significant at $0.1 \% . \chi^{2}=$ Chi Square. $V_{i}=$ Company dummies. All Probabilities are reported within parentheses.

It is apparent from Table 8 that the model has quite a high degree of variability with R-squared of $59.21 \%$. Furthermore, the significant Wald $\chi^{2}$ indicates that the model is fit. With regard to the significance of the individual regressors (CEP, LOG_CO, GOR, GPR and GUI), it can be inferred from Table 8 that size (measured by LOG_CO) and GOR do not have significant impacts on SDI. GPR and GUI, on the other hand, have significant positive impact on SDI. The interpretation of the significant positive effect of GPR on SDI is that the higher the price of natural gas, the more motivated oil and gas companies become to disclose more hard and specific GFR information. Closely related to the positive influence of GPR on SDI, is the significant positive effect of GUI on SDI. Thus, the significant positive impact of GUI on SDI implies that increases in ANG utilization investments by the oil and gas companies, results in decreases in carbon emission due to gas flaring. Because this represents a manifestation of positive environmental behavior, the companies are keen to report more of this information.

The result in Table 8 on the effect of CEP on SD1 indicates that the two variables are significantly negatively associated. This result is used to test $\mathrm{H} 2 \mathrm{~b}$, which sates, in null form, that Gas flaring-related environmental performance is not negatively associated with disclosure substance of gas flaring-related information by dominant companies in the Nigerian upstream sector. Thus, the co-efficient of CEP is negative (-0.404844), and this implies that CEP has negative influence on SDI. Not only that this relationship is negative, but it is also significant. Therefore, on the basis of this result, we can reject the null hypothesis, and it can be concluded that GFR environmental performance and the degree of substance of GFR environmental disclosure, are significantly negatively associated. Indeed, this result provides evidence in support of legitimacy theory in the context of a less-developed country, and hence, in general, consistent with the findings reported by Patten (1992), Hughes et al (2001), Patten (2002), Cho et al (2006), Cho \& Patten (2007), and de Villier \& van Staden (2011). Moreover, this result implies that dominant companies in the upstream sector of the Nigerian oil and gas industry use hard GFR disclosures that portray them in good light to legitimize their ANG production and flaring activities. In fact, positive GFR disclosures were by far much more than negative disclosures in the reports of the samples companies' operators.

\section{Discussion of results}

To provide empirical evidence that would facilitate meeting the first objective of this paper, the first hypothesis (H1a) has been developed from the proposition of voluntary disclosure theory. Consistent with voluntary disclosure theory, the statistical test of this hypothesis reveals that GFR environmental performance and GFR volumetric disclosure are significantly positively associated. In line with this theory and the unanimous results reported by AlTuwaijri et al (2004), Clarkson et al (2008) and Dawkins \& Fraas (2011b), this finding means that companies, with poor GFR environmental performance, tend to disclose less GFR environmental information in order not to make their poor environmental responsibility behavior obvious. Moreover, this finding supports the argument of this study, that companies operating in less-developed countries are likely to report less environmental information as their environmental performances get poorer. We argue that this reporting behavior is consistent with vulnerability of Nigeria as a less developed country. Thus, the dominant oil and gas companies only report more GFR environmental information if they record better performance. Consequently, it is convenient for these companies to exhibit this reporting pattern because pressure for them to be accountable for their poor performance could easily be managed due to weaknesses in government, pressure groups and common Nigerians. These weaknesses are the products of inherent vulnerability of the country (see, Belal et al. 2013). In addition, this finding also suggests that GFR environmental performance is one of the key factors responsible for the undulating trend in the volume of firms' environmental disclosures across units and over time, as documented by such African empirical studies as Tsang (1998), Jamil et al. (2002) and de Villiers \& van Staden (2006).

The second hypothesis $(\mathrm{H} 2 \mathrm{~b})$, derived from legitimacy theory, was developed as a mechanism for meeting the second objective of this article. The results presented and interpreted in section 4 reveal that there is significant negative relation between GFR environmental performance and GFR environmental disclosure substance. Therefore, consistent with legitimacy theory dominant oil and gas companies operating in the upstream sector of the Nigerian oil and gas industry use disclosure of hard GFR environmental information that is specific, quantitative and/or textual, to legitimize their ANG production and flaring activities. This finding is particularly consistent with the conclusions reported by Patten (2002), Cho et al (2006); Cho \& Patten (2007) in terms of the nature of the relationship. Essentially, the finding means that in the context of Nigeria, a less developed country, dominant oil and gas companies managed by foreign operators tend to legitimize their associated gas production and flaring activities using 'hard' GFR environmental disclosures that depict them in good light. This finding suggests the existence of GFR reporting activities carried out by these companies to take advantage of the exploitable nature of Nigeria. More specifically, this empirical evidence implies that dominant oil and gas companies disclose especially more specific and quantitative gas flaring information that enhances their good image to legitimize continuous exploitation of oil and gas resources in Nigeria. Interestingly, this evidence unveils further insight into legitimacy theory on how companies operating in vulnerable and exploitable lessdeveloped countries use this practice as a disclosure tool for increasing and elongating resource exploitation. They do this by providing verifiable and specific information about good things done or being planned in respect of utilization of ANG, reduction of carbon emission due to the flaring or a direct reduction of the gas being flared to generate, for example, electricity. Consistent with the argument put forward by Limdblom (1994) the dominant companies use this reporting strategy to manipulate or change $\mathrm{Ni}$ - 
gerians' perception about their GFR poor performance using specific and verifiable information showing them in good position.

\section{Conclusion}

This study submits new insights into legitimacy theory and voluntary disclosure theory using specific empirical evidence on GFR environmental performance and disclosure from the Nigerian oil and gas industry. The study connects the voluntary and legitimizing disclosure behavior regarding carbon emission due to gas flaring by dominant companies in the Nigerian upstream sector to the vulnerability and exploitability of the country as a less developed country. We also provide empirical evidence confirming that environmental performance is one of the key factors responsible for the undulating trend in the volume of corporate environmental disclosures in less-developed countries. We specifically explicate the unique contributions and originality of this study's findings to the environmental performance and disclosure relationship literature as follows.

First, our result provides more insights into, and further evidence on, the rise and fall in environmental disclosures by MNCs in lessdeveloped countries, based on the influence of environmental performance on such disclosures. This is because previous studies, such as Tsang (1998), Jamil et al. (2002) and de Villiers \& van Staden (2006) that document empirical evidence about undulating trends regarding corporate environmental disclosures in lessdeveloped countries, have not provided explanations concerning any factor/s responsible for such trends. However, in this study, we submit empirical evidence that the significant effect of GFR carbon emission performance is among the factors responsible for the rise and fall in GFR carbon emission disclosure over time and across companies. We, of course, admit that environmental performance may not be the only factor that could explain the initial rise and subsequent fall. Consequently, further research is required to examine other factors.

Secondly, we empirically document that the volume of GFR information disclosed by dominant companies in the Nigerian upstream sector is positively associated with GFR carbon emission performance. This positive relation between the two variables represents empirical evidence confirming the vulnerable nature of Nigeria as a less developed country. This suggests that dominant oil and gas companies would only increase gas flaring-related disclosures if their performance is on the rise and would reduce such disclosures if they happen to record poor performance. In this context, we contend that governments and other relevant environmental stakeholders in the country are weak at challenging this reporting behavior due to the vulnerable nature of the country. In addition, our empirical evidence reveals negative relation between GFR carbon performance and the corresponding degree of GFR disclosure substance. This negative relation reflects the efforts by oil and gas companies to increase the rate at which they are exploiting Nigeria's oil and gas resources. The exploitable nature of Nigeria makes it such that any specific and verifiable information that can be shown as having linkage to possible reduction of poverty and improved standard of living is acceptable. Indeed, even if it means excessive exploitation of resources, waste of resources or consequent environmental degradation. Indeed, linking and explaining the negative and positive relation between GFR carbon emission performance and its corresponding substance and volumetric disclosures to the vulnerability and exploitability of Nigeria as a less developed constitutes another significant contribution of this research.

Third, although, we include eleven dominant oil and gas companies operating in the Nigerian oil and gas upstream sector, the carbon performance and reporting practices of these companies are tracked over a period of thirteen years. Consequently, we are confronted with finite (small) TS-CS dataset (Wooldridge 2002, Beck 2001). A number of robust regression techniques appropriate for our dataset have been developed. These include fixed effect model (see, Green et al. 2001, Wooldridge 2002), Feasible Generalized
Least Squares (FGLS) and Panel Corrected Standard Errors (PCSE) (Beck \& Karz 1995, 1996, Beck 2001). Given the structure and attributes of our dataset, we come to the conclusion that PraisWisnten regression with PCSEs is more appropriate and robust for our analysis. Moreover, absence of a ready-made and specifically applicable environmental performance measures for the companies in our sample necessitates the search for a robust measurement strategy. Although, we came across a number of generally applicable measurement strategies, in especially accounting and management literature, that could be used in our study, we decided to use DEA, a measurement strategy commonly used in environmental economics literature. Our decision to select this technique over the ones used in accounting and management is informed by some features possessed by the tool, which make it more efficient and robust. These features are (i) DEA is rigorously developed in the literature of environmental economics; (ii) the approach is underpinned by the theory of productive efficiency and (iii) it is standardized and hence generally applicable. Indeed, the two methods employed portray this current paper as unique among environmental performance and disclosure relationship studies.

It is almost impossible for any research to be absolutely flawless due to the fallible nature of human beings who conduct the research activity. In this respect, this study also has its limitations as identified and discussed as follows. Firstly, although, the assumption of 'constant return to scale' is certainly well-established and the most commonly applied when measuring environmental performance using DEA, some of the results of this study might have differed had 'variable return to scale' been assumed. However, since this study uses a DEA approach that excludes inputs, it is safer to assume 'constant return to scale'. Secondly, by defining the population of the study as consisting those companies whose gas flaring and other related oil and gas information must be available in the NNPC's ASBs, we have constructed a reality to which the findings and arguments of this research apply (see, Hines 1988). Consequently, the arguments and findings of this paper may not be applicable to the cases of some less-developed countries that have succeeded in reducing ANG flaring to the barest minimum level. Similarly, the results may also not be applicable to GFR environmental accountability in the Nigerian downstream sector.

\section{Acknowledgement}

We gratefully acknowledge the invaluable assistance provided by Maryam Hassan. The first author acknowledges financial support provided by Petroleum Technology Development Fund (PTDF) of Nigeria.

\section{References}

[1] Abbott, W. F., \& Monsen, R. G. (1979) On the measurement of corporate social responsibility: Self-reported disclosure as a method of measuring corporate social involvement. Academy of Management Journal, 22(3), 501-515.

[2] Ahmad, N. S. (2004) Corportae environmental disclosure in Libya: Evidence and environmental deterministic theory. [Ph.D. Thesis]: Napier University, United Kingdom.

[3] Ahmad, Z., Hassan, S., \& Mohammad, J. (2003) Determinants of environmental reporting in Malaysia. International Journal of Business Studies, 11(1), 69-90.

[4] Al-Tuwaijri, S. A., Christensen, T. E., \& Hughes II, K. E. (2004) The relations among environmental disclosure, environmental performance, and economic performance: A simultaneous equations approach Accounting Organization and Society, 29, 447-471.

[5] Ann, E. G., Zailani, S., \& Wahid, N. A. (2006) A study on the impact of Environmental Mangement System (EMS) towards firms' performance in Malaysia. Management of Environmental Quality: An International Journal, 17, 73-93.

[6] Arrow, K., Bolin, B., Costanza, R., Dasgupta, B., Folke, C., Hollin, C. S., et al. (1995) Economic growth, carrying capacity, and the environment. Ecological Economics, 15(2), 91-95. 
[7] Ascui, F., \& Lovell, H. (2011) As frames collide: Making sense of carbon accounting. Accounting, Auditing \& Accountability Journal, 24(8), 978-999.

[8] Ascui, F., \& Lovell, H. (2012) Carbon accounting and the construction of competence. Journal of Cleaner Production, 36, 48-59.

[9] Beck, A. C., Campbell, D., \& Shrives, P. J. (2010) Content analysis in environmental reporting research: Enrichment and rehearsal of the method in a British-German context. The British Accounting Reviews, 42, 207-222.

[10]Beck, N. (2001) Time-series-cross-section data: What have we learned in the past few years? Annual Review of Political Science, 4, 271-29.

[11]Beck, N., \& Katz, J. N. (1995) What to do (and not to do) with Timeseries-cross-section data in comparative politics. The American Political Science Review, 89(3), 634-647.

[12]Beck, N., \& Katz, J. N. (1996) Nuisance v. substance: Specifying and estimating time-series cross-section models. Political Analysis, 6(1), 136.

[13]Beck, N., \& Katz, J. N. (2007) Random coefficient models for timeseries-cross-section data: Monte Carlo experiments. Political Analysis, 15(2), 182-195.

[14]Belal, A. R., Cooper, S. M., \& Robin, W. R. (2013) Vulnerable and exploitable: The need for organizational accountability and transparency in emerging and less developed countries. Accounting Forum, 37(2), 81-91.

[15]Berry, M. A., \& Rondinelli, D. A. (1998) Proactive corporate environmental management: A new industrial revolution. Academy of Management Journal, 12(2), 38-50.

[16]Bewley, K., \& Li, Y. (2000) The disclosure of environmental liabilities by Canadian manufacturing companies: A voluntary disclosure perspective. Advances in Environmental Accounting and Management, 1, 201-226.

[17]Blaikie, P., Cannon,, T., Davis, I., \& Wisner, B. (1994) At risk: Natural hazards, people's vulnerability and disasters. London: Routledge.

[18]Campbell, D. (2000) Legitimacy theory or managerial reality construction: Corporate social disclosure in Mark Spencer corporate reports 1969-1997. Accounting Forum, 24(1), 80-100.

[19]Campbell, D. (2004) A longitudinal and cross-sectional analysis of environmental disclosure in UK companies - A research note. The British Accounting Review, 36, 107-117.

[20]Campbell, D. J. (2003) Intra- and inter-sectoral effects in environmental disclosures: Evidence for legitimacy theory? Business Strategy and the Environment, 12(6), 357-371.

[21]Caves, D. W., Christensen, L. R., \& Diewert, E. W. (1982) Multilateral comparison of output, input and productivity using superlative index number. Economic Journal, 92(365), 73-86.

[22]Cho, C. H., Patten, D. M., \& Roberts, R. W. (2006) Corporate political strategy: An examination of the relation between political expenditures, environmental performance, and environmental disclosure. Journal of Business Ethics, 67(2), 139-154.

[23]Cho, C. H., Roberts, R. W., \& Patten, D. M. (2010) The language of US corporate environmental disclosure. Accounting Organisation and Society, 35(4), 431-443.

[24]Cho, H. C., \& Patten, D. (2007) The role of environmental disclosures as tools of legitimacy: A Research note. Accounting Organizations and Society, 32(7-8), 639-647.

[25]Choi, J.-S. (1998) An evaluation of the voluntary corporate environmental disclosures: A Korean evidence. Social and Environmental Accountability, 18(1), 2-8.

[26]Clarkson, P. M., Li, Y., Richardson, G. D., \& Vasvari, F. P. (2008) Revisiting the relation between environmental performance and environmental disclosure: An empirical analysis. Accounting Organisation and Society, 33(4-5), 303-327.

[27]Clarkson, P. M., Overell, M. B., \& Chapple, L. (2011) Environmental reporting and its relation to environmental performance. ABACUS A Journal of Accounting, Finance and Business Studies, 27(1), 47-60.

[28]Cooper, W. W., Seiford, L. M. \& Tone, K. (2007) Data envelopment analysis: A comprehensive text with models, applications, references and DEA-solver software. New York: Springer.

[29]Cormier, D., \& Magnan, M. (1997) Investors' assessment of implicit environmental liabilities: An empirical investigation. Journal of Accounting and Public Policy, 16(2), 215-241.

[30]Cuesta, R. A., Lovell, C. K., \& Zofio, J. L. (2009) Environmental efficiency measurement with trans-log distance functions: A parametric approach. Ecological Economics, 68, 2232-2242.

[31]Dawkins, C. E., \& Fraas, J. W. (2011a) Erratum to: Beyond acclamations and excuses: environmental performance, voluntary environmental disclosure and the role of visibility. Journal of Business Ethics, 97(1), 244-282.
[32]Dawkins, C. E., \& Fraas, J. W. (2011b) Coming clean: The impact of environmental performance and visibility on corporate climate-change disclosure. Journal of Business Ethics, 100, 303-322.

[33]de Villiers, C., \& van Staden, C. J. (2006) Can less environmental disclosure have a legitimizing effect? Evidence from Africa. Accounting Organisation and Society, 31(8), 763-781.

[34]de Villiers, C., \& van Staden, C. J. (2011) Where firms choose to disclose voluntary environmental information. Journal of Accounting and Public Policy, 30(6), 504-525.

[35]Deegan, C., \& Gordon, B. (1996) A study of environmental disclosure practices of Australian corporations. Accounting and Business Research, 26(3), 187-199.

[36]Deegan, C., \& Rankin, M. (1996) Do Australian companies report environmental news objectively? An analysis of environmental disclosures by firms prosecuted successfully by environmental protection authority. Accounting, Auditing \& Accoutability Journal, 9(2), 50-67.

[37]Desjardins, J. R. (2001) Environmental Ethics: An introduction to environmental philosophy (3rd ed.) Belmont: Wadswoth/Thomson Learning.

[38]Disu, A., \& Gray, R. (1998) An exploration of social reporting and MNCs in Nigeria. Social and Environmental Accountability Journal, 18(2), 13-15.

[39]Dowling, J., \& Pfeffer, J. (1975) Organizational legitimacy: Social values and organizational behavior. The Pacific Sociological Review, 18(1), 122-136.

[40]Dye, R. A. (1985) Disclosure of nonproprietary information. Journal of Accounting Research, 23(1), 123-145.

[41]Elijido-Ten, E. (2011) Media coverage and voluntary environmental disclosures: A developing country exploratory experiment. Accounting Forum, 35(3), 139-157.

[42]Färe, R., Grosskopf, S., \& Hernandez-Sancho, F. (2004) Environmental performance: An index number approach. Resource and Energy Economics, 26(4), 343-352.

[43]Färe, R., Grosskopf, S., \& Pasurka Jr., C. A. (2006) Social Responsibility: U.S. power plants: 1985-1998. J Prod Anal, 26(3), 259267.

[44]Färe, R., Grosskopf, S., \& Tyteca, D. (1996) Activity analysis model of the environmental performance of firms. Application to fossil-fuelfired electric utilities. Ecological Economics, 18(2), 161-175.

[45]Färe, R., Grosskopf, S., \& Whittaker, G. (2004) Distance functions with applications to DEA. In W. W. Cooper, L. M. Seiford, J. Zhu, W. W. Cooper, L. M. Seiford, \& J. Zhu (Eds.), Handbook on Data Envelopment Analysis (pp. 139-52) Boston: Kluwer Academic Publishers.

[46]Färe, R., Grosskopf, S., Lovell, C. A., \& Pasurka, C. (1989) Multilateral productivity comparison when some output are undesirable: A nonparametric approach. The Review of Economics and Statistics, 71(1), 90-98.

[47]Färe, R., Grosskopf, S., Lovell, C. A., \& Yaisawarng, S. (1993) Derivation of shadow price for undesirable output: A nonparametric approach. Review of Economics and Statistics, 75(2), 374-380.

[48]Färe, R., Grosskopf, S., Noh, D.-W., \& William, W. (2005) Characteristics of a polluting technology: Theory and practice. Journal of Econometrics, 126(2), 469-492.

[49]Farrell, M. J., 1957. Measurement of productive efficiency. Journal of the Royal Statistical Society, 120(3), pp. 253-290.

[50]Freedman, M., \& Jaggi, B. (1982) Pollution disclosures, pollution performance and economic performance. Omega: The International Journal of Management Science, 10(2), 167-176.

[51]Freedman, M., \& Jaggi, B. (2005) Global warming, commitment to the Kyoto Protocol, and accounting disclosure by the largest global public firms from polluting industries. The International Journal of Accounting, 40(3), 215-232.

[52]Freedman, M., \& Wasley, C. (1990) The association between environmental performance and environmental disclosure in annual reports and 10Ks. Advances in Public Interest Accounting, 3, 183-193.

[53]Gimenez, G. L., Casadesus, M. F., \& Valls, J. P. (2003) Using environmental management system to increase firms' competitiveness. Corporate Social Resposnibility and Environmental Management, 10, 101-110.

[54]Gray, R., Kouhy, R. \& Lavers, S., 1995. Corporate social and environmental reporting: a review of literature and longitudinal study of UK disclosure. Accounting, Auditing and Accountability Journal, 8(2), pp. 47-77.

[55]Green, D. P., Kim, S. Y. \& Yoon, D. H. (2001) Dirty pool. International Organisation, 55(2), 441-468.

[56]Griffin, J. J., \& Mahon, J. F. (1997) The corporate social performance and corporate financial performance debate: Twenty-five years of incomparable research. Business \& Society, 36(1), 5-31 
[57]Guthrie, J., \& Parker, L. D. (1990) Corporate social disclosure practice: A comparative international analysis. Advances in Public Interest Accounting, 3, 159-75.

[58]Hines, R. D., (1988) Financial accounting: in communicating reality, we construct reality. Accounting Organisation and Sciety, 13(3), pp. 251-261.

[59]Holsti, O. (1969) Content analysis for the social sciences and humanities. Massachusetts: Addison-Wsley Publishing Company.

[60]Horváthová, E. (2010) Does environmental performance affect financial performance? A meta-analysis. Ecological Economics, 70(1), 52-59.

[61]Hua, Z., \& Bian, Y. (2007) DEA with undesirable factors. In J. Zhu, W. D. Cook, J. Zhu, \& W. D. Cook (Eds.), Modelling data irregularities and structural complexities in data envelopment analysis (pp. 03-121) New York: Springer Science+Business Media.

[62]Hughes, S. B., Anderson, A., \& Golden, S. (2001) Corporate environmental disclosures: Are they useful in determining environmental performance? Journal of Accounting and Public Policy, 20(3), 217-240.

[63]Ilinitch, A. Y., Soderstrom, N. S., \& Thomas, T. E. (1998) Measuring corporate environmental performance. Journal of Accounting and Public Policy, 17(4-5), 383-408.

[64]Ingram, R. W., \& Frazier, K. B. (1980) Environmental performance and corporate disclosure. Journal of Accounting Research, 18(2), 614622 .

[65]Iraldo, F., Testa, F., \& Frey, M. (2009) Is an environmental management system able to influence environmental and competitive performance? The case of the eco-management and audit scheme (EMAS) in the European Union. Journal of Cleaner Production, 17(16), 1444-1452.

[66]Jamil, C. M., Alwi, K., \& Mohamed, R. (2002) Corporate social responsibility disclosure in the annual reports of Malaysian companies: A longitudinal study. Social and Environmental Accountability Journal, 22(2), 5-9.

[67]Johnstone, N., \& Labonne, J. (2009) Why do manufacturing facilities introduce environmental management systems? Improving and/or signaling performance. Ecological Economics, 68(3), 719-730.

[68]Konar, S., \& Cohen, M. (2001) Does the market value environmental performance? Review of Economics and Statistics, 83(2), 281-309.

[69]KPMG. (2008) KPMG International survey of corporate responsibility reporting 2008. USA: KPMG International.

[70]Krippendorff, K. (2004) Content analysis: An introduction to its methodology (Second ed.) Thousand Oaks: Sage Publications.

[71]Li, Y., Richardson, G. D., \& Thornton, D. B. (1997) Corporate disclosure of environmental liability information: Theory and Evidence. Contemporary Accounting Research, 14(3), 435-474.

[72]Lindblom, C. K. (1994) The implications of organizational legitimacy for corporate social performance and disclosure. New York: paper presented at Critical Perspectives on Accounting Conference.

[73]López-Gamero, M. D., Molina-Azorín, J. F., \& Clever-Cotés, E. (2009) The whole relationship between environmental variables and firm performance: Competitive advantage and firm resources as mediator variables. Journal of Environmental Management, 90(10), 3110-3121.

[74]Mahadeo, J. D., Oogarah-Hanuman, V., \& Soobaroyen, T. (2011) Changes in social and environmental reporting practices in an emerging economy (2004-2007): Exploring the relevance of stakeholder and legitimacy theories. Accounting Forum, 35(3), 158175.

[75]Mathews, M. R. (1993) Social responsibility accounting. London: Chapman and Hall

[76]Montalbano, P. (2011) Trade openness and developing countries' vulnerability: Concepts, misconceptions, and directions for research. World Development, 39(9), 1489-1502.

[77]Nawrocka, D., \& Parker, T. (2009) Finding the connection: environmental management systems and environmental performance. Journal of Cleaner Production, 17(6), 601-607.

[78]O'Donovan, G. (2002) Environmental disclosures in the annual report: Extending the applicability and predictive power of legitimacy theory. Accounting, Auditing and Accouniability Journal, 15(3), 344-371.

[79]Orlitzky, M., Schmidt, F. L., \& Rynes, S. L. (2003) Corporate social and financial performance: A meta-analysis. Organisation Studies, 23(3), 404-441.

[80]Parker, L. D. (2005) Social and environmental accountability research: A view from the commentary box. Accounting, Auditing \& Accountability Journal, 18(6), 842-860.

[81]Patten, D. M. (1992) Intra-industry environmental disclosures in response to the Alaskan oil spill: A note on legitimacy theory. Accounting Organizations and Society, 17(5), 471-475.
[82]Patten, D. M. (2002) The relation between environmental performance and environmental disclosure: A research note. Accounting, Organizations and Society, 27(8), 763-773.

[83]Perotto, E., Canziani, R., Marchesi, R., \& Butelli, P. (2008) Environmental performance, indicators and measurement uncertainty in EMS context: A case study. Journal of Cleaner Production, 16(4), 517-530.

[84]Pittman, R. W. (1983) Multilateral productivity comparisons with undesirable outputs. Economic Journal, 93(372), 883-891.

[85]Plümper, T., \& Troeger, V. E. (2005) Panel data analysis in comparative politics: Linking method to theory. European Journal of Political Research, 44(2), 327-354.

[86]Podestà, F. (2006) Comparing time-series cross-section model specifications: The case of welfare state development. Quality \& Quantity, 40(4), 539-559.

[87]Rahman, S. A., Yusoff, R. b., \& Mohamed, W.-N. b. (2009) Environmental disclosure and financial performance: An empirical study of Malaysia, Thailand and Singapore. Social and Environmental Accountability Journal, 29(2), 46-58.

[88]Scipioni, A., Manzardo, A., Mazzi, A., \& Mastrobuono, M. (2012) Monitoring the carbon footprint of products: A methodological proposal. Journal of Cleaner Production, 36, 94-101.

[89]Seiford, L. M., \& Zhu, J. (2002) Modeling undesirable factors in efficiency evaluation. European Journal of Operational Research, 142(1), 16-20.

[90]Shephard, R. W. (1970) Theory of cost and production functions. Princeton, NJ: Princeton University Press.

[91]Siddiqui, J. (2001) Environmental non-accountability in Bangladesh?: The striking case of the magurchara gas field disaster. Social and Environmental Accountability Journal, 21(2), 12-13.

[92] Smith, M. (2003) Research Methods in Accounting. London: Sage

[93]Stechemesser, K., \& Guenther, E. (2012) Carbon accounting: a systematic literature review. Journal of Cleaner Production, 36, 17-38.

[94]Sulaiman, M., \& Ahmad, N. (2002) ISO 14001 and corporate performance: A survey of certified companies in Malaysia. Retrieved August 13, 2010, from Environmental Expert: www.environmentalexpert.com

[95]Sullivan, R., \& Gouldson, A. (2012) Does voluntary carbon reporting meet investors' needs? Journal of Cleaner Production, 36, 60-67.

[96]Sumiani, Y., Haslinda, Y., \& Lehman, G. (2007) Environmental reporting in a developing country: A case study on status and implementation in Malaysia. Journal of Cleaner Production, 15(10), 895-901.

[97]Tsai, W.-H., Shen, Y.-S., Lee, P.-L., Chen, H.-C., Kuo, L., \& Huang, C.-C. (2012) Integrating information about the cost of carbon through activity-based costing. Journal of Cleaner Production, 36, 102-111.

[98]Tsang, E. W. (1998) A longitudinal study of corporate social reporting in Singapore: The case of the banking, food and beverages and hotel industries. Accounting Auditing and Accountability Journal, 11(15), 624-635.

[99]Tyteca, D. (1996) On the measurement of the environmental performance of firms- A literature review and a productive efficiency perspective. Journal of Environmental Management, 46(3), 281-308.

[100]Tyteca, D. (1997) Linear programming models for the measurement of environmental performance of firms-concepts and empirical results. Journal of Productivity Analysis, 8(2), 183-197.

[101]van Staden, C. J., \& Hooks, J. (2007) A Comprehensive comparison of corporate environmental reporting and responsiveness. The British Accounting Review, 39, 197-210.

[102]Verrecchia, R. E. (1983) Discretionary disclosure. Journal of Accounting and Economics, 5, 79-194.

[103]Waddock, S. A., \& Graves, S. B. (1997) The corporate social performance-financial performance link. Strategic Management Journal, 18(4), 303-319.

[104]Wiseman, J. (1982) An evaluation of environmental disclosures made in corporate annual reports. Accounting Organization and Society, 7(1), 53-63.

[105]Wood, D. J. (1991) Corporate social performance revisited. The Academy of Management Review, 16(4), 691-718.

[106]Wooldridge, J. M. (2002) Introductory econometrics: A modern approach (Second ed.) US: South Western Educational Publishing.

[107]Zaim, O. (2004) Measuring environmental performance of state manufacturing through changes in pollution intensities: A DEA framework. Ecological Economics, 48(1), 37-47.

[108]Zeghal, D., \& Ahmed, S. A. (1990) Comparison of social resposibility information disclosure media used by Canadian firms. Accounting Auditing and Accountability Journal, 3(1), 38-53.

[109]Zhou, P., Ang, B. W., \& Han, J. Y. (2009) Total factor carbon emission performance: A Malmquist index analysis. Energy Economics, 32(1), 194-201 
[110]Zhou, P., Ang, B., \& Poh, K. (2006) Slacks-based efficiency measures for modeling environmental performance. Ecological Economics, 60(1), 111-118. 